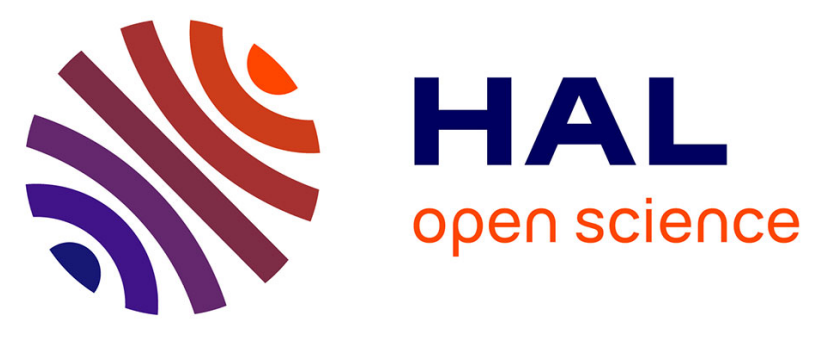

\title{
Staphylococcal ecosystem of kitoza, a traditional malagasy meat product
}

\author{
Angela Ratsimba, Sabine Leroy, Jean-Paul Chacornac, Danielle Rakoto, \\ Elodie Arnaud, Victor Jeannoda, Régine Talon
}

\section{To cite this version:}

Angela Ratsimba, Sabine Leroy, Jean-Paul Chacornac, Danielle Rakoto, Elodie Arnaud, et al.. Staphylococcal ecosystem of kitoza, a traditional malagasy meat product. International Journal of Food Microbiology, 2017, 246, pp.20-24. 10.1016/j.ijfoodmicro.2017.02.001 . hal-01602697

\section{HAL Id: hal-01602697 https://hal.science/hal-01602697}

Submitted on 26 May 2020

HAL is a multi-disciplinary open access archive for the deposit and dissemination of scientific research documents, whether they are published or not. The documents may come from teaching and research institutions in France or abroad, or from public or private research centers.
L'archive ouverte pluridisciplinaire HAL, est destinée au dépôt et à la diffusion de documents scientifiques de niveau recherche, publiés ou non, émanant des établissements d'enseignement et de recherche français ou étrangers, des laboratoires publics ou privés. 


\title{
Staphylococcal ecosystem of kitoza, a traditional malagasy meat product
}

\author{
Angela Ratsimba a , Sabine Leroy ${ }^{b}$, Jean Paul Chacornac ${ }^{b}$, Danielle Rakoto ${ }^{a}$, Elodie Arnaud ${ }^{c, d}$, \\ Victor Jeannoda ${ }^{a}$, Régine Talon ${ }^{\mathrm{b}, *}$
}

${ }^{a}$ UT, Université d'Antananarivo, Faculté des Sciences, Madagascar

${ }^{\mathrm{b}}$ MIC, INRA, 63122 Saint-Genès-Champanelle, France

c UMR QUALISUD, CIRAD, 7602 Stellenbosch, South Africa

d UMR QUALISUD, CIRAD, 34398 Montpellier, France

\section{A R T I C L E I N F O}

\section{Article history:}

Received 30 August 2016

Received in revised form 31 January 2017

Accepted 1 February 2017

Available online 02 February 2017

\section{Keywords:}

Kitoza

Beef

Pork

Smoking

Sun-drying

Staphylococcus

\begin{abstract}
A B S T R A C T
Kitoza is a traditional meat product from Madagascar manufactured with strips of pork or beef. The process includes a first step of salting and mixing with spices followed by sun-drying or smoking step. As salting and drying select coagulase-negative staphylococci (CNS), our aim was to identify the CNS species in kitoza with the objective in the future of developing indigenous starters. Microbial analyses revealed that the only pathogenic bacterium enumerated was Staphylococcus aureus, which was found in $54 \%$ of the samples. The level of Enterobacteriaceae revealed a rather good hygienic quality of these products. CNS were confirmed in all the samples at high levels ranging from 5 to $7 \mathrm{log} \mathrm{cfu} / \mathrm{g}$. Identification of CNS species in a large collection of 829 isolates revealed 9 identified species, 7 for beef and 8 for pork kitoza. There were significant difference in the distribution of CNS species according to the type of meat and the process. Staphylococcus saprophyticus was the dominant species for sun-dried or smoked beef and sun-dried pork kitoza (73-75\%), while for smoked pork kitoza Staphylococcus equorum (26\%), S. saprophyticus (23\%), Staphylococcus succinus (23\%) and Staphylococcus epidermidis (17\%) co-dominated. Some CNS could be used as indigenous starters in particular to compete against S. aureus.
\end{abstract}

(c) 2017 Published by Elsevier B.V.

\section{Introduction}

Salting, smoking and drying are among the oldest methods of meat preservation. In tropical countries, where the climate and environmental conditions promote the rapid degradation of meat and where there is sometimes a lack of adequate facilities for the storage of raw meat, traditional processing techniques are often based on the use of these single or combined operations. They lead to a wide variety of products such as biltong in South Africa (Petit et al., 2014), kilishi in Nigeria (Kalilou et al., 1998), boucané in Réunion Island (Poligne et al., 2001), charqui in Brazil (Pinto et al., 2002) and kitoza in Madagascar (Santchurn et al., 2012).

Kitoza is a traditional meat product from Madagascar manufactured with strips of either pork or beef. It is produced in rural and urban regions by artisans and families following traditional processes and sold in local markets. In a first step of the process, miscellaneous pieces of pork and beef meats are cut into strips approximately $2-4 \mathrm{~cm}$ thick and $20-50 \mathrm{~cm}$ long and are salted with coarse salt mixed with spices such as garlic, pepper, and ginger. Then, a sun-drying and/or smoking step is carried out.

\footnotetext{
* Corresponding author at: INRA, UR Microbiologie, 63122 Saint-Genès Champanelle, France.

E-mail address: regine.talon@inra.fr (R. Talon).
}

Depending on the products, a wide range of water activity $\left(\mathrm{a}_{\mathrm{w}}\right)$ and salt content have been recorded. They varied from low $\mathrm{a}_{\mathrm{w}}(0.65-0.68)$ and high $\mathrm{NaCl}$ concentration (5.5-7.9 g/100 g) in dry commercial biltong to higher $\mathrm{a}_{\mathrm{w}}(0.85-0.89)$ and lower salt content (3.8-5.6 g/100 g) in moist commercial biltong (Petit et al., 2014). The $\mathrm{a}_{\mathrm{w}}$ of beef and pork jerky varied from 0.83 to 0.79 and the $\mathrm{a}_{\mathrm{w}}$ of traditional làcon was 0.90 (Lorenzo et al., 2015; Yang et al., 2009). Also, the pH of these products varied from 5.0 to 6.2 (Lorenzo et al., 2015; Petit et al., 2014; Yang et al., 2009). The total microbial viable count is usually high in dried salted meat products, for instance 6 to $9 \log$ CFU/g in biltong or in làcon, and the salt-tolerant microbiota was the dominant population.

Coagulase-negative staphylococci (CNS) are halotolerant and thus one of the dominant microbiota of salted/dried/fermented meat products (Leroy et al., 2015; Lorenzo et al., 2015; Pinto et al., 2002). In fermented sausages, CNS enhance color stability, prevent rancidity by inhibiting oxidation of unsaturated free fatty acids and release aromatic substances (Coppola et al., 1997; Papamanoli et al., 2002; Talon and Leroy, 2006). In jerked beef, a derivative of charqui meat, staphylococci represent the dominant microbiota and the inoculation of Staphylococcus xylosus as starter culture leads to products preferred by the sensory panel (Pinto et al., 2002). Meat-associated CNS are able to produce bacteriocins that may contribute to bioprotection against meat pathogens, in particular Clostridium botulinum and Staphylococcus aureus (Sanchez Mainar et al., 2016). For instance, species usable as starter cultures 
such as S. xylosus and Staphylococcus equorum have been shown able to produce bacteriocin (Laukovà et al., 2010; Sanchez Mainar et al., 2016). Thus, CNS could contribute both to the sensory qualities and the bioprotection of meat products (Talon and Leroy, 2006).

No data were available about identification of CNS from kitoza and the aim of this study was to identify these bacteria at the species level in kitoza made from beef or pork and either sun-dried or smoked and collected from producers at different sites. These genetic resources can be used to develop indigenous starters that could be applied to product biopreservation. At the same time, a global view of the microbiology of kitoza is given as well as some of the physicochemical properties important for microbial quality.

\section{Materials and methods}

\subsection{Samples}

A total of 54 kitoza samples ready for consumption were collected in butcheries, markets or supermarkets in or near Antananarivo (Madagascar). They included 27 samples of beef kitoza (13 smoked, 14 dried) and 27 of pork kitoza ( 14 smoked, 13 dried).

The kitoza products were manufactured according the two steps described in introduction with a lot of variation in the process. Samples were kept at $4{ }^{\circ} \mathrm{C}$ before microbial analyses and stored at $-20^{\circ} \mathrm{Cfor}$ physicochemical analyses.

\subsection{Physicochemical analyses}

The salt content was measured with the Model 926 Chloride Analyzer (Sherwood Scientific, Cambridge, UK) after $2 \mathrm{~h}$ of cold extraction in $0.3 \mathrm{~N}$ nitric acid. Water activity was measured at $25{ }^{\circ} \mathrm{C}$ with a Fast-lab water activity meter (GBX, Romans, France). The pH was measured with a TitroLine ${ }^{\circledR}$ easy titrator (SI Analytics GmbH, Mainz, Germany) after homogenization of $3 \mathrm{~g}$ samples with $27 \mathrm{~mL}$ of distilled water for $30 \mathrm{~min}$. These analyses were carried out on the 54 samples in duplicates.

\subsection{Microbial analyses}

Microbial analyses of the 54 samples were performed on selective media in duplicate. The total counts, yeasts and molds, staphylococci, lactic acid bacteria (LAB), Enterobacteriaceae, coagulase positive staphylococci and S. aureus, Listeria monocytogenes and Salmonella were analyzed as described by Lebert et al. (2007). In particular, the presence of $S$. aureus isolated from Baird Parker agar supplemented with tellurite yolk egg was confirmed by the Pastorex Staph-Plus test, a latex agglutination test for the identification of S. aureus (Bio-Rad, Marnes La Coquette, France). For LAB, the MRS media was incubated under anaerobic conditions. In addition, Bacillus cereus was numerated on $\mathrm{Ba}$ cillus cereus Selective Agar (Oxoid, USA), incubated at $30^{\circ} \mathrm{C}$ for $18-48 \mathrm{~h}$; Clostridium perfringens on Tryptose Sulfite Agar (Biokar, France), incubated at $37^{\circ} \mathrm{C}$ for $20 \mathrm{~h}$ and confirmed with Lactose Sulfite medium (Biokar, France) at $46{ }^{\circ} \mathrm{C}$.

A collection of 829 isolates of staphylococci was constituted by selecting for each sample an average of 15 colonies on countable plates of Mannitol Salt Agar (MSA, Bio-Rad, France, Leroy et al., 2010). These isolates were cultivated on Brain Heart Infusion (BHI, Difco, USA) at $30{ }^{\circ} \mathrm{C}$ overnight. They were then stored at $-80^{\circ} \mathrm{C}$ in BHI broth containing glycerol $20 \%$ before identification.

\subsection{Identification of the CNS isolates}

Firstly, all the isolates were grown on BHI agar $\left(24 \mathrm{~h}, 30^{\circ} \mathrm{C}\right)$. Amplifications were performed from one colony picked from the agar plate of each isolate with the primers TstaG422 (5'-GGC CGT GTT GAA CGT GGT CAA ATC A-3') and Tstag765 (5'-TTA CCA TTT CAG TAC CTT CTG GTA A- $3^{\prime}$ ) from the tuf gene allowing the identification the Staphylococcus genus, as described by Martineau et al. (2001).

Secondly, the isolates belonging to the Staphylococcus genus were further identified at the species level by a species-specific oligonucleotide array as described by Giammarinaro et al. (2005). The primers D1 (CCITAYICITAYGAYGCIYTIGARCC) and D2 (ARRTARTAIGCRTGYTCCCAIACRTC) were used to amplify the sodA gene by PCR. This PCR product was labeled with digoxigenin, heat denatured and hybridized with the species-specific oligonucleotide probes fixed to a nylon membrane. The hybridized targets were detected with the Dig color detection kit (Roche, Meylan, France).

\subsection{Statistical analysis}

The statistical analyses were performed with the XLStat program, version 2016 (Addinsoft, Paris, France). Physicochemical parameters and microbial counts of the four types of kitoza were compared using analysis of variance. Tukey's HSD least significant difference was used with a level of significance of 95\%. To test for independence between combinations of Staphylococcus species and type of kitoza, the Chisquare $\left(\chi^{2}\right)$ test was used.

\section{Results and discussion}

\subsection{Physicochemical characteristics}

Kitoza belongs to a wide variety of low and intermediate moisture meat products obtained after salting, drying, and sometimes smoking. In our study, the average salt content and the average water activity of the kitoza products varied from 2.64 to $4.15 \mathrm{~g} / 100 \mathrm{~g}$ and from 0.83 to 0.96 , respectively (Table 1 ). There were significant differences in water activity $(P<0.05)$ between smoked and dried products, the smoked ones being less dry than the dried ones. Significant differences in salt content were only noticed between pork kitoza samples, the dried ones being more salty than the smoked ones. The water activity of smoked kitoza was of the same order as that of traditional làcon (Lorenzo et al., 2015) while that of dried kitoza was of the same order as that of biltong, a salted dried product (salt content from 3.8 to $7.9 \mathrm{~g} / 100 \mathrm{~g}$ ) made from beef, kudu, springbok or chicken (0.65-0.89) (Petit et al., 2014). Similarly, the water activity of traditional fermented sausages from Greece, Spain, France or Argentina varies from 0.79 to 0.91 (GarcíaFontán et al., 2007a; García Fontán et al., 2007b; Leroy et al., 2015).

The $\mathrm{pH}$ of the beef kitoza samples, either dried (5.67) or smoked (5.87) (Table 1), was in the same range as the $\mathrm{pH}$ of fresh beef (5.5 to 5.9; Laurent, 1981). The $\mathrm{pH}$ of the smoked pork kitoza (6.08, Table 1) was in the range of the $\mathrm{pH}$ of the fresh raw pork meat (5.7 to 6.2; Laurent, 1981), while the $\mathrm{pH}$ of the dried pork kitoza (6.45, Table 1) was higher. Thus, in pork samples, the process affected the $\mathrm{pH}$ as dried pork products had a significantly higher $\mathrm{pH}(P<0.05)$ than the smoked ones (Table 1). Similar pH ranges were found in biltong samples (5.00 to 6.26) (Petit et al., 2014), beef and pork jerky (5.53-6.07) (Yang et al., 2009) and traditional dry cured làcon (5.00 to 6.00) (Lorenzo et al., 2015).

Table 1

Physicochemical parameters of kitoza.

\begin{tabular}{llll}
\hline Sample & $\begin{array}{l}\text { Water activity } \\
\text { Mean } \pm \text { SD }\end{array}$ & $\begin{array}{l}\text { Salt content }(\mathrm{g} / 100 \mathrm{~g}) \\
\text { Mean } \pm \mathrm{SD}\end{array}$ & $\begin{array}{l}\mathrm{pH} \\
\text { Mean } \pm \mathrm{SD}\end{array}$ \\
\hline Smoked beef $(n=13)$ & $0.94 \pm 0.02^{\mathrm{a}}$ & $2.83 \pm 0,81^{\mathrm{a}, \mathrm{b}}$ & $5.87 \pm 0.17^{\mathrm{b}, \mathrm{c}}$ \\
Dried beef $(n=14)$ & $0.86 \pm 0.06^{\mathrm{b}}$ & $3.61 \pm 1.21^{\mathrm{a}, \mathrm{b}}$ & $5.67 \pm 0.18^{\mathrm{c}}$ \\
Smoked pork $(n=14)$ & $0.96 \pm 0.02^{\mathrm{a}}$ & $2.64 \pm 1.13^{\mathrm{b}}$ & $6.08 \pm 0.55^{\mathrm{b}}$ \\
Dried pork $(n=13)$ & $0.83 \pm 0.07^{\mathrm{b}}$ & $4.15 \pm 1.85^{\mathrm{a}}$ & $6.45 \pm 0.31^{\mathrm{a}}$ \\
\hline
\end{tabular}

n: number of samples; SD: standard deviation; ${ }^{\text {a,b,c. }}$ mean values in the same column not followed by a common letter differ significantly $(P<0.05)$. 


\subsection{Microbiota}

Microbial analyses revealed the absence of pathogenic bacteria such as Salmonella and only one smoked beef sample out of 54 samples was contaminated by L. monocytogenes. Furthermore, B. cereus ( $<2 \log \mathrm{cfu} / \mathrm{g}$ ) and $C$. perfringens ( $<1 \log \mathrm{cfu} / \mathrm{g}$ ) were not detected. Levels of $S$. aureus were recorded ranging from 2.7 to $3.6 \log \mathrm{cfu} / \mathrm{g}$, but with high variability, as attested by the maximum level ( $4.7 \mathrm{log} \mathrm{cfu} / \mathrm{g}$ ) or by no detection $(<2.0 \log \mathrm{cfu} / \mathrm{g}$ ) (Table 2). The number of smoked samples contaminated was inferior to the dried ones: 8 beef and 9 pork smoked samples were below the detection threshold compared with 5 beef and 3 pork dried samples (Table 2). Similar variability in contamination by coagulase-positive staphylococci was noticed for different dried meat products. They were not detected in charqui meats (Pinto et al., 2002) while S. aureus was identified in South African biltong (Mhlambi et al., 2010). S. aureus and L. monocytogenes were able to survive during biltong manufacturing (Naidoo and Naidoo and Lindsay, 2010). The enumeration of Enterobacteriaceae, albeit variable, attested the hygienic quality of the final products (Table 2). In particular, for the majority of the smoked products, Enterobacteriaceae were under the detection threshold (Table 2).

The enumeration of yeasts and molds was significantly higher in the dried pork kitoza (Table 2). These microorganisms could contribute to the high $\mathrm{pH}$ in these products (Table 1 ) due to their ability to degrade lactate (Berni, 2015; Selgas and Garcia, 2015). Yeasts and molds were found in làcon and in biltong (Lorenzo et al., 2015; Petit et al., 2014). The two co-dominant populations were represented by lactic acid bacteria and coagulase-negative staphylococci, which ranged from approximately 5 to $7 \log \mathrm{cfu} / \mathrm{g}$ (Table 2). The average total count was not significantly different between the samples.

The population enumerated on MSA was largely dominated by staphylococci as all the 829 isolates from MSA were identified as belonging to the genus Staphylococcus by using the genus-specific PCR. The presence of salt together with the low moisture content explains the high halotolerant staphylococcal population. This level of staphylococcal population was also found in làcon and in charqui (Lorenzo et al., 2015; Pinto et al., 2002). High levels of LAB were noted in biltong (Petit et al., 2014). In most traditional fermented sausages, staphylococci constituted the second microbiota at the end of the ripening after the lactic acid bacteria and reached a population that ranged from 4.0 to $7.0 \log$ cfu/g (GarcíaFontán et al., 2007a; García Fontán et al., 2007b; Leroy et al., 2015).
The microbial ecosystem of kitoza has been studied by a classical culture-dependent analysis that gives an image dependent on selective media. A culture-independent approach would have revealed great genus diversity, but could have led to the non-identification of certain species as shown by Greppi et al. (2015). In our study, with the aim of characterizing the diversity of Staphylococcus species and creating a collection for potential starter development, it was necessary to isolate the strains and identify them by appropriate molecular methods.

\subsection{Inventory of the CNS species in beef and pork kitoza}

Nine Staphylococcus species were identified from a large collection of 829 isolates, including 423 from beef and 406 from pork kitoza samples (Table 3). One to five species could be identified per sample, but in the majority of the samples two species were concomitantly isolated (data not shown). Concerning the diversity of CNS species in beef and pork kitoza, seven species were identified in beef, while eight species were identified in pork with six species in common (Table 3). This CNS species diversity has already been observed in French dry fermented sausages and in the manufacturing environment, from eight species in a collection of 204 isolates in the study of Coton et al. (2010), up to fifteen species in a collection of 676 isolates in the study of Leroy et al. (2010). Seven CNS species have been identified in botillo and five in androlla, two Spanish traditional smoked pork sausages (GarcíaFontán et al., 2007a; García Fontán et al., 2007b). In kadid, a Tunisian traditional salted dried beef product, nine species have been identified (Essid et al., 2007). These CNS species could originate from the animals as they were part of the microbiota of their skin and mucous membranes (Nagase et al., 2001).

In kitoza, four main species were isolated, including Staphylococcus saprophyticus (60.8\%), S. xylosus (11.3\%), Staphylococcus succinus (9.8\%) and Staphylococcus equorum (8.2\%) (Table 3). It is noteworthy that the four main species found in kitoza constituted the dominant CNS species in foods of animal origin, even if they were in different ratios. Thus, in fermented foods (cheeses and sausages), S. equorum represented $28.5 \%$, S. xylosus $28.3 \%$, S. saprophyticus $12.5 \%$ and S. succinus $7.7 \%$ (Coton et al., 2010). In traditional French sausages, the following ratios were found: S. equorum (58.2\%), S. saprophyticus (11.9\%), S. xylosus (11.3\%) and S. succinus (7.7\%) (Leroy et al., 2010). These species were prevalent in two Italian traditional sausages, sopressata Ricigliano and Gioi (Mauriello et al., 2004) and in salami (Połka et al., 2015). These four species were also identified in biltong (Mhlambi et al., 2010). In

Table 2

Microbial analyses of kitoza.

\begin{tabular}{|c|c|c|c|c|c|c|}
\hline Samples & T. count & Entero* & $\mathrm{Y} / \mathrm{M}^{*}$ & $\mathrm{LAB}$ & CNS & S. aureus* \\
\hline \multicolumn{7}{|c|}{ Smoked beef $(n=13)$} \\
\hline Mean \pm SD & $6.1 \pm 1.6^{\mathrm{b}}$ & $2.3 \pm 1.7^{\mathrm{a}}$ & $2.8 \pm 1.2^{\mathrm{b}}$ & $5.8 \pm 1.6^{\mathrm{b}}$ & $5.3 \pm 1.8^{\mathrm{b}}$ & $3.1 \pm 1.3^{\mathrm{a}}$ \\
\hline Max & 8.4 & 5.0 & 4.4 & 8.2 & 8.1 & 4.6 \\
\hline Min & 4.0 & $<1.0(8)$ & $<1.0(5)$ & 3.5 & 3.0 & $<2.0(8)$ \\
\hline \multicolumn{7}{|c|}{ Dried beef $(n=14)$} \\
\hline Mean \pm SD & $6.8 \pm 0.9^{\mathrm{a}, \mathrm{b}}$ & $2.9 \pm 1.0^{\mathrm{a}}$ & $3.6 \pm 1.0^{\mathrm{b}}$ & $6.7 \pm 1.0^{\mathrm{a}, \mathrm{b}}$ & $6.7 \pm 1.0^{\mathrm{a}, \mathrm{b}}$ & $3.6 \pm 1.0^{\mathrm{a}}$ \\
\hline Max & 8.2 & 4.3 & 5.0 & 8.3 & 8.1 & 4.7 \\
\hline Min & 5.3 & $<1.0(3)$ & 1.6 & 5.1 & 4.5 & $<2.0(5)$ \\
\hline \multicolumn{7}{|c|}{ Smoked pork $(n=14)$} \\
\hline Mean \pm SD & $7.3 \pm 1.2^{\mathrm{a}}$ & $2.3 \pm 1.1^{\mathrm{a}}$ & $3.8 \pm 1.3^{\mathrm{b}}$ & $7.3 \pm 1.1^{\mathrm{a}}$ & $6.5 \pm 1.5^{\mathrm{a}, \mathrm{b}}$ & $2.7 \pm 0.7^{\mathrm{a}}$ \\
\hline Max & 8.9 & 3.3 & 6.1 & 8.3 & 9.0 & 3.6 \\
\hline Min & 4.8 & $<1.0(11)$ & 2.0 & 4.9 & 4.0 & $<2.0(9)$ \\
\hline \multicolumn{7}{|c|}{ Dried pork $(n=13)$} \\
\hline Mean \pm SD & $7.8 \pm 0.9^{\mathrm{a}}$ & $3.7 \pm 1.0^{\mathrm{a}}$ & $5.3 \pm 1.5^{\mathrm{a}}$ & $7.3 \pm 0.9^{\mathrm{a}}$ & $7.2 \pm 1.1^{\mathrm{a}}$ & $3.5 \pm 0.8^{\mathrm{a}}$ \\
\hline Max & 9.1 & 4.7 & 8.6 & 8.7 & 9.4 & 4.6 \\
\hline Min & 6.9 & $<1.0(4)$ & 3.6 & 5.5 & 5.6 & $<2.0$ (3) \\
\hline
\end{tabular}

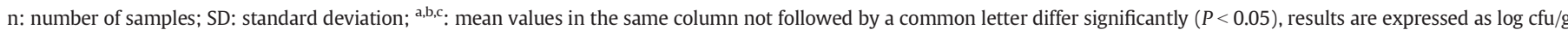

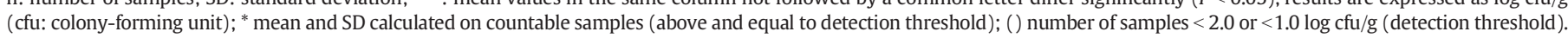
T. count: total count; Entero: Enterobacteriaceae; Y/M: yeast and mold; LAB: lactic acid bacteria; CNS: coagulase-negative staphylococci. 
Table 3

Inventory of the coagulase-negative species in the sun-dried and smoked beef and pork kitoza $(\chi 2=427, P<0.0001)$.

\begin{tabular}{|c|c|c|c|c|c|}
\hline Staphylococcus & Total & $\begin{array}{l}\text { Smoked } \\
\text { beef }\end{array}$ & Dried beef & $\begin{array}{l}\text { Smoked } \\
\text { pork }\end{array}$ & $\begin{array}{l}\text { Dried } \\
\text { pork }\end{array}$ \\
\hline Isolates & 829 & 229 & 194 & 210 & 196 \\
\hline S. saprophyticus & $504(60.8)$ & $167(72.9)$ & $141(72.7)$ & 49 (23.3) & $147(75.0)$ \\
\hline S. xylosus & $94(11.3)$ & $22(9.6)$ & $19(9.8)$ & $20(9.5)$ & $33(16.8)$ \\
\hline S. succinus & $81(9.8)$ & $19(8.3)$ & $9(4.6)$ & $48(22.9)$ & $5(2.6)$ \\
\hline S. equorum & $68(8.2)$ & $6(2.6)$ & $2(1.0)$ & $55(26.2)$ & $5(2.6)$ \\
\hline S. epidermidis & $35(4.2)$ & & & 35 (16.7) & \\
\hline S. kloosii & $21(2.5)$ & $1(0.4)$ & 19 (9.8) & $1(0.5)$ & \\
\hline S. sciuri & $13(1.6)$ & $4(1.7)$ & $4(2.1)$ & & $5(2.6)$ \\
\hline S. warneri & $10(1.2)$ & $10(4.3)$ & & & \\
\hline S. vitulinus & $3(0.4)$ & & & $2(1.0)$ & $1(0.5)$ \\
\hline
\end{tabular}

Numbers in brackets represent the number of isolates as a percentage of the total.

kadid, S. equorum, S. saprophyticus and S. xylosus were equally distributed in the range of 22 and 26\% (Essid et al., 2007).

\subsection{Diversity of the CNS species in the sun-dried or smoked beef and pork kitoza}

There were significant difference $(\chi 2=427, P<0.0001)$ in the distribution of CNS species according to the type of meat and the process. The percentages of S. saprophyticus (about 73\%) and S. xylosus (about $10 \%$ ) were similar in smoked and dried beef kitoza, while they were higher, particularly for S. saprophyticus (75\%), in dried pork than in smoked pork (23.3\%) (Table 3). These two species also constituted an important part of the CNS microbiota in Greek salami and sausage (Samelis et al., 1998; Drosinos et al., 2005), làcon (Vilar et al., 2000), botillo (GarcíaFontán et al., 2007a) and in various Italian sausages (Aquilanti et al., 2007; Coppola et al., 2000; Mauriello et al., 2004). For sucuk, a fermented beef product, S. xylosus and S. saprophyticus were the dominant species (41.5\% and 28.5\%, respectively) (Kaban and Kaya, 2008). Taylor (1976) found that S. saprophyticus was dominant in biltong from beef.

The percentages of S. succinus (22.9\%) and S. equorum (26.2\%) were quite similar and the highest in the smoked pork kitoza, while the occurrence of these two species was low in beef kitoza and in dried pork kitoza (Table 3). These two species were found to be co-dominant in traditional pork sausages (Corbière Morot-Bizot et al., 2006) and identified in salami (Greppi et al., 2015). S. equorum was also isolated in Italian (Aquilanti et al., 2007; Blaiotta et al., 2004; Coppola et al., 2000; Mauriello et al., 2004; Villani et al., 2007), and Spanish sausages (García Fontán et al., 2007b) and in biltong (Mhlambi et al., 2010).

S. epidermidis (16.7\%) was only found in smoked pork kitoza (Table 3). S. epidermidis has already been identified in Greek salami and botillo, two smoked pork sausages (García Fontán et al., 2007b; Samelis et al., 1998). It has also been isolated from Spanish sausages: chorizo, fuet and salchichon (Martín et al., 2006). S. warneri was only identified in the smoked beef kitoza samples. S. epidermidis and S. warneri were the predominant staphylococci found on human skin (Nagase et al., 2001) and could be transferred to meat during the processing. Like dried beef kitoza, biltong was not contaminated by S. warneri (Mhlambi et al., 2010). S. warneri was found in the Spanish sausages mentioned above and in different Italian sausages (Coppola et al., 2000; Iacumin et al., 2006; Mauriello et al., 2004; Rantsiou et al., 2005). S. kloosii was missing in dried pork kitoza while it represented a non-negligible percentage (9.8\%) in dried beef kitoza and a minor population in the smoked beef and pork kitoza (Table 3). S. sciuri was not found in smoked pork kitoza and $S$. vitulinus represented a minor population only in pork kitoza (Table 3). S. sciuri and S. kloosii constituted the minor population of a Tunisian salted dried beef meat "kadid" (Essid et al., 2007).

\section{Conclusion}

Traditional meat kitoza products had similar physicochemical characteristics to other traditional salted, dried meat products. The kitoza products studied did not present hygienic problem and among the potential pathogens researched, only S. aureus was enumerated. Staphylococci constitute an important microbial population in kitoza and a high diversity of CNS species was found, Staphylococcus saprophyticus being the dominant species isolated from both beef and pork kitoza. The diversity in CNS species varied according to the type of meat-pork or beef, and the process-sun-dried or smoked. Knowledge of the CNS species could lead to the development of competitive indigenous starters that could be applied to product biopreservation and could help to control S. aureus as some strains are able to produce bacteriocins (Sanchez Mainar et al., 2016).

As LAB constituted the co-dominant bacteria in these products, it will be interesting in the future to identify the different species and formulate mixed starter cultures composed of CNS and LAB. In a previous study on the acceptance and sensory profiling of kitoza, inclusion of commercial bioprotective cultures composed of one CNS and one LAB confirmed the value of this strategy for these kinds of products (Pintado et al., 2016).

\section{Acknowledgements}

This work was financially supported by the European project: African Food Revisited by Research (AFTER, http://www.after-fp7.eu), FP7 245-025. The authors are grateful to David Marsh for correcting our English.

\section{References}

Aquilanti, L., Santarelli, S., Silvestri, G., Osimani, A., Petruzzelli, A., Clementi, F., 2007. The microbial ecology of a typical Italian salami during its natural fermentation. Int. J. Food Microbiol. 120, 136-145.

Berni, E., 2015. Molds. In: Toldrá, F., Hui, Y.H., Astiasarán, I., Sebranek, J.G., Talon, R. (Eds.), Handbook of Fermented Meat and Poultry, second ed. Wiley-Blackwell, pp. 147-153.

Blaiotta, G., Pennacchia, C., Villani, F., Ricciardi, A., Tofalo, R., Parente, E., 2004. Diversity and dynamics of communities of coagulase-negative staphylococci in traditional fermented sausages. J. Appl. Microbiol. 97, 271-284.

Coppola, R., Iorizzo, M., Saotta, R., Sorrentino, E., Grazia, L., 1997. Characterization of micrococci and staphylococci isolated from soppressatamolisana, a Southern Italy fermented sausage. Food Microbiol. 14, 47-53.

Coppola, S., Mauriello, G., Aponte, M., Moschetti, G., Villani, F., 2000. Microbial succession during ripening of Naples-type salami, a southern Italian fermented sausage. Meat Sci. 56, 321-329.

Corbière Morot-Bizot, S., Leroy, S., Talon, R., 2006. Staphylococcal community of a small unit manufacturing traditional dry fermented sausages. Int. J. Food Microbiol. 108, 210-217.

Coton, E., Desmonts, M.H., Leroy, S., Coton, M., Jamet, E., Christieans, S., Donnio, P.Y., Lebert, I., Talon, R., 2010. Biodiversity of coagulase-negative staphylococci in French cheeses, dry fermented sausages, processing environments and clinical samples. Int. J. Food Microbiol. 137, 221-229.

Drosinos, E.H., Mataragas, M., Xiraphi, N., Moschonas, G., Gaitis, F., Metaxopoulos, J., 2005. Characterization of the microbial flora from a traditional Greek fermented sausage. Meat Sci. 69, 307-317.

Essid, I., Ismail, H.B., Ahmed, S.B.H., Ghedamsi, R., Hassouna, M., 2007. Characterization and technological properties of Staphylococcus xylosus strains isolated from a Tunisian traditional salted meat. Meat Sci. 77, 204-212.

García Fontán, M.C., Lorenzo, J.M., Parada, A., Franco, I., Carballo, J., 2007b. Microbiological characteristics of "androlla," a Spanish traditional pork sausage. Food Microbiol. 24, $52-58$.

GarcíaFontán, M.C., Lorenzo, J.M., Martínez, S., Franco, I., Carballo, J., 2007a. Microbiological characteristics of Botillo, a Spanish traditional pork sausage. LWT- Food Sci. Technol. 40, 1610-1622.

Giammarinaro, P., Leroy, S., Chacornac, J.P., Delmas, J., Talon, R., 2005. Development of a new oligonucleotide array to identify staphylococcal strains at species level. J. Clin. Microbiol. 43, 3673-3680.

Greppi, A., Ferrocino, I., La Storai, A., Rantsiou, K., Ercolini, D., Cocolin, L., 2015. Monitoring of the microbiota of fermented sausages by culture independent rRNA-based approaches. Int. J. Food Microbiol. 212, 67-75.

Iacumin, L., Comi, G., Cantoni, C., Cocolin, L., 2006. Ecology and dynamics of coagulase negative staphylococci isolated from naturally fermented Italian sausages. Syst. Appl. Microbiol. 29, 480-486. 
Kaban, G., Kaya, M., 2008. Identification of lactic acid bacteria and Gram-positive catalasepositive cocci isolated from naturally fermented sausage (Sucuk). J. Food Sci. 73, 385-388.

Kalilou, S., Collignan, A., Zakhi, N., 1998. Optimizing the traditional processing of beef into Kilishi. Meat Sci. 5, 21-32.

Laukovà, A., Simonovà, M., Strompfovà, V., 2010. Staphylococcus xylosus S03/1 M/1/2, bacteriocin-producing meat starter culture or additive. Food Control 21, 970-973.

Laurent, C., 1981. Conservation des produits d'origine animale en pays chauds.InIEMVT (Ed.). Centre de Documentation et des Archives, Paris, France, pp. 157-159.

Lebert, I., Leroy, S., Giammarinaro, P., Lebert, A., Chacornac, J.P., Bover I Cid, S., Vidal, C., Talon, R., 2007. Diversity of microorganisms in the environment and dry fermented sausages of small traditional French processing units. Meat Sci. 76, 112-122.

Leroy, S., Giammarinaro, P., Chacornac, J.P., Lebert, I., Talon, R., 2010. Biodiversity of indigenous staphylococci of naturally dry sausages and manufacturing environments of small-scale processing units. Food Microbiol. 27, 294-301.

Leroy, S., Lebert, I., Talon, R., 2015. Microorganisms in traditional fermented meats. In: Toldrá, F., Hui, Y.H., Astiasarán, I., Sebranekand, J.G., Talon, R. (Eds.), Handbook of Fermented Meat and Poultry, second ed. Wiley-Blackwell, pp. 99-105.

Lorenzo, J.M., Bermúdez, R., Domínguez, R., Guiotto, A., Franco, D., Purriños, L., 2015. Physicochemical and microbial changes during the manufacturing process of dry-cured lacón salted with potassium, calcium and magnesium chloride as a partial replacement for sodium chloride. Food Control 50, 763-769.

Martín, B., Garriga, M., Hugas, M., Bover-Cid, S., Veciana-Nogues, M.T., Aymerich, T., 2006. Molecular, technological and safety characterization of Gram-positive catalase-positive cocci from slightly fermented sausages. Syst. Appl. Microbiol. 107, 148-158.

Martineau, F., Picard, F.J., Ke, D., Paradis, S., Roy, P.H., Ouellette, M., Bergeron, M.G., 2001. Development of a PCR assay for identification of staphylococci at genus and species levels. J. Clin. Microbiol. 39, 2541-2547.

Mauriello, G., Casaburi, A., Blaiotta, G., Villani, F., 2004. Isolation and technological properties of coagulase negative staphylococci from fermented sausages of Southern Italy. Meat Sci. 67, 149-158.

Mhlambi, S.G., Naidoo, K., Lindsay, D., 2010. Enterotoxin-producing Staphylococcus strains associated with South African biltongat point of sale. J. Food Saf. 30, 307-317.

Nagase, N., Sasaki, A., Yamashita, K., Shimizu, A., Wakita, Y., Kitai, S., Kawano, J., 2001. Isolation and species distribution of staphylococci from animal and human skin. J. Vet. Med. Sci. 64, 245-250.

Naidoo, K., Lindsay, D., 2010. Survival of Listeria monocytogenes, and enterotoxin-producing Staphylococcusaureus and Staphylococcus pasteuri, during two types of biltonmanufacturing processes. Food Control 21, 1042-1050.

Papamanoli, E., Kotzekidou, P., Tzanetakis, N., Litopoulou-Tzanetaki, E., 2002. Characterization of Micrococcaceae isolated from dry fermented sausages. Food Microbiol. 19, 441-449.

Petit, T., Caro, Y., Petit, A.S., Santchurn, S.J., Collignan, A., 2014. Physicochemical and microbiological characteristics of biltong, a traditional salted dried meat of South Africa. Meat Sci. 96, 1313-1317.
Pintado, A.I.E., Monteiro, M.J.P., Talon, R., Leroy, S., Scislowski, V., Fliedel, G., Rakoto, D. Maraval, I., Costa, A.I.A., Silva, A.P., Pallet, D., Tomlins, K., Pintado, M.M.E., 2016. Consumer acceptance and sensory profiling of reengineered kitoza products. Food Chem. 198, 75-84.

Pinto, M.F., Ponsano, E.H.G., Franco, B.D.G.M., Shimokomaki, M., 2002. Charqui meats as fermented meat products: role of bacteria for some sensorial properties development. Meat Sci. 61, 187-191.

Poligne, I., Collignan, A., Trystram, G., 2001. Characterization of traditional processing of pork meat into boucané. Meat Sci. 59, 377-389.

Połka, J., Rebecchi, A., Pisacane, V., Morelli, L., Puglisi, E., 2015. Bacterial diversity in typical Italian salami at different ripening stages as revealed by high-throughput sequencing of $16 \mathrm{~S}$ rRNA amplicons. Food Microbiol. 46, 342-356.

Rantsiou, K., Iacumin, L., Cantoni, C., Comi, G., Cocolin, L., 2005. Ecology and characterization by molecular methods of Staphylococcus species isolated from fresh sausages. Int J. Food Microbiol. 97, 277-284.

Samelis, J., Metaxopoulos, J., Vlassi, M., Pappa, A., 1998. Stability and safety of traditional Greek salami - a microbiological ecology study. Int. J. Food Microbiol. 44, 69-82.

Sanchez Mainar, M., Ageliki Stravopoulou, D., Leroy, F., 2016. Exploring the metabolic heterogeneity of coagulase negative staphylococci to improve the quality and safety of fermented meats: a review. Int. J. Food Microbiol. http://dx.doi.org/10.1016/j. ijfoodmicro.2016.05.021.

Santchurn, S.J., Arnaud, E., Zakhia-Rozis, N., Collignan, A., 2012. Drying: principles and applications. In: Hui, Y.H. (Ed.), Handbook of Meat and Meat Processing. Bosa Roca:CRC Press Inc/Taylor and Francis Group, pp. 505-530.

Selgas, M.D., Garcia, M.L., 2015. Yeasts. In: Toldrá, F., Hui, Y.H., Astiasarán, I., Sebranek, J.G. Talon, R. (Eds.), Handbook of Fermented Meat and Poultry, second ed. Wiley-Blackwell, pp. 139-146.

Talon, R., Leroy, S., 2006. Latest developments in meat bacterial starters. In: Nollet, L.M.L., Toldra, F. (Eds.), Advanced Technologies for Meat Processing. CRC Press/Taylor and Francis Group, New York, pp. 401-418.

Taylor, B., 1976. Changes in microbial flora during biltong production. SA Food Rev. 3 $120-123$.

Vilar, I., Fontán, G., Prieto, B., Tornadijo, M.E., Carballo, J., 2000. A survey on the microbiological changes during the manufacture of dry-cured lacón, a Spanish traditional meat product. J. Appl. Microbiol. 89, 1018-1026.

Villani, F, Casaburi, A Pennacchia, C. Filosa, L, Russo, F Ercolini, D, 2007. Microbial ecology of the soppressata of Vallo di Diano, a traditional dry fermented sausage from Southern Italy, and in vitro and in situ selection of autochthonous starter cultures. Appl. Environ. Microbiol. 73, 5453-5463.

Yang, H.S., Hwang, Y.H., Joo, S.T., Park, G.B., 2009. The physicochemical and microbiological characteristics of pork jerky in comparison to beef jerky. Meat Sci. 82, 289-294. 